\title{
Liquidity versus Profitability: A Study on Hindustan Unilever Limited
}

\author{
Radhagobinda Basak*
}

\begin{abstract}
As per the general notion, liquidity should have an opposite relationship with profitability. In case of Hindustan Unilever Limited, it has been observed that with the passage of time, the company was able to improve both its liquidity and profitability. The present paper seeks to understand the reason behind this contradictory result. As per the findings of the paper, intelligent debtors and creditors management helped the company significantly in achieving higher profitability along with higher liquidity.
\end{abstract}

Keywords: Liquidity; Profitability; Debtors turnover ratio; Creditors turnover ratio.

\subsection{Introduction}

Liquidity refers to the capability to meet the short term obligations of a firm. To meet short term obligations, short term assets are needed. Therefore, the higher the amount of short term assets, the higher is the liquidity. On the other hand, profitability refers to the capability to earn profit which is measured by return on investment. Investment may be of two types- investment in long term assets and investment in short term assets. If investment in short term asset is increased, total investment will go up. As a result, rate of return on investment will come down means profitability will fall. With the increase in investment in short term assets, liquidity will improve. Therefore, liquidity and profitability move in opposite direction. This notion is commonly known as liquidity-profitability tangle.

Profitability can't be increased limitlessly by reducing liquidity. If liquidity is not sufficient, a firm will not be able to meet its short term obligations. As a result, production may be hampered; credit taking capability may be reduced. So, ultimately, profit will be adversely affected.

*Assistant Professor, Department of Commerce, Sidho-Kanho-Birsha University, Purulia, West Bengal, India. (Email id: rgbasak85@gmail.com) 
Again, extreme liquidity blocks investment unnecessarily in short term assets. This will also affect profitability adversely. For this reason, liquidity management is very important so far as the question of profitability is concerned. In this background, an attempt has been taken in this paper to analyse the nature of relationship between liquidity and profitability of Hindustan Unilever Limited (HUL). HUL belongs to fast moving consumer goods (FMCG) industry. In FMCG industry, liquidity management is comparatively more important because huge amount of investment in short term asset is required there. HUL is the largest company in India in this sector in terms of revenue or profit or market capitalization. The company has a long experience and established goodwill in this business line. Considering these points, HUL has been selected in this study.

The remaining portion of the study is divided into five sections. Section 2 provides a brief review of literature in this field. Section 3 outlines the objectives of the study along with the research methodology. Analysis and findings have been discussed in section 4. Conclusion has been discussed in the last section.

\subsection{Review of Literature}

This section provides a review of some studies that have examined the relationship of liquidity and profitability to different types of variables. Sur et. al. (2013) showed how deregulation, globalisation and liberalisation brought changes in the liquidity management of the public sector undertakings in India. In their case study on BHEL, they measured the correlation between liquidity and profitability in the postliberalization era. The study found significant declining trend in liquidity but significant upward trend in profitability. A significant negative correlation was found between liquidity and profitability. The study also found that the influence of inventory management, debtors' management and cash management on the overall profitability of the company was not significant. Later, Aziz et. al. (2017) found the same type of significant negative correlation between liquidity and profitability while analysing the relationship between liquidity management and profitability of Islamic banks of Kurdistan Region of Iraq. In another study, negative correlation between liquidity and profitability was also found in case of Coal India Ltd. though the correlation was weak (Shivakumar \& Thimmaiah, 2016).

Asaduzzaman and Chowdhury (2014) examined the relationship between working capital management (WCM) and profitability of textile industry in Bangladesh. The study used multiple regression models to analyse the relationship between WCM and profitability. It was found that there is positive relationship between number of days 
of inventory and profitability; and between number of days accounts receivable and profitability. Profitability and number of day's accounts payable was negatively correlated. The study considered cash conversion cycle (CCC) as the comprehensive measure of working capital management and found positive association between CCC and profitability. In an earlier study, Ajao and Small (2012) echoed same type of findings based on a case study on selected manufacturing companies listed on the Nigerian Stock Exchange. As per their findings, a good level of liquidity management, as measured by credit policies, cash flow management and cash conversion cycle, had significant positive impact on corporate profitability.

Tamragundi and Vaidya (2016) conducted a study for finding out the liquidityprofitability relationship in the context of ten leading FMCG companies in India. They found a significant positive relationship between profitability and liquidity for all ten leading FMCG companies. Positive relation between liquidity and profitability was also found by Ahmad (2016) when he analysed liquidity and profitability status of Standard Chartered Bank, Pakistan but the said correlation was weak. Bandyopadhyay (2012) analysed the relationship between liquidity and profitability in Indian corporate sector during the post liberalisation period. Ten industries were selected for the study. Fifty companies were included in the sample taking five companies from each selected industry. The study found positive association between CR and ROCE; ITR and ROCE; DTR and ROCE; CATA and ROCE; CTR and ROCE but negative association between QR and ROCE in majority of the cases. As per the study, the joint influence of the selected six indicators of liquidity management on profitability was not significant in majority of the companies. Later, such type of mixed results was also experienced by Chukwunweike (2014). The study was conducted on companies listed on Nigerian Stock Exchange. A significant positive correlation between current ratio and ROA was found but there was no definite significant relationship between acid test ratio and ROA. In this connection, Alshatti (2015) too obtained mixed results while defining the effect of liquidity management on profitability in the context of Jordanian Commercial Banks. As per the findings of the study, quick ratio and investment ratio had positive effect on profitability but capital ratio and liquid assets ratio had negative effect on profitability.

Das (2012) conducted a study to analyse the working capital management of Hindustan Unilever Limited. The study showed a rapid increase in gross working capital (GWC) of the company. GWC was more relied on current assets rather than fixed assets. A decreasing trend of dependence on long term fund as a source of working capital was followed. The study showed that the company adopted moderately aggressive working capital policy which helped to increase its profitability. Arora (2013) examined the impact of negative working capital on profitability of Hindustan Unilever Limited. A 
positive association between net profit and net working capital was found in the study. Positive growth rate was followed in sales, net profit and operating profit. Negative working capital had no adverse effect on the profitability of the company.

Bhunia, et. al. (2011) measured the effectiveness of liquidity and solvency on profitability of the private sector steel companies in India. The study found a significant positive association between liquidity and profitability but solvency position did not have any effect on profitability. In a similar type of study on the chemical sector of Pakistan, Khidmat \& Rehman (2014) found that liquidity had high positive effect over ROA and ROE but Solvency ratio had highly significant negative impact on the ROA and ROE. The present paper is an attempt to understand the relationship between profitability and liquidity in the context of Hindustan Unilever Limited.

\subsection{Objectives and Research Methodology}

\subsection{Objectives}

The objectives of the present study are as follows:

(i) To analyse the state and trend of liquidity of HUL;

(ii) To analyse the state and trend of profitability of HUL; and

(iii) To analyse the nature and degree of association between liquidity and profitability of HUL.

\subsection{Research methodology}

The study is based on secondary data which have been collected from the published annual reports of the company from 2005 to 2014-15. To measure the liquidity seven ratios have been used in the study- Current ratio (CR), Quick ratio (QR), Inventory turnover ratio (ITR), Debtors turnover ratio (DTR), Absolute cash ratio (ACR), Creditors turnover ratio (CDTR) and Current assets to total assets (CATA). Three ratios, namely, Return on net worth (RONW), Return on capital employed (ROCE) and Return on Assets (ROA) have been used to measure the profitability. To examine the trend of liquidity and profitability during the study period, straight line trend has been fitted and through t-test, significance of slopes of trend lines has been tested. To estimate the degree of uniformity among the sets of liquidity ranks and among the sets of profitability ranks, Kendall's Coefficient of Concordance has been computed whose significance has been tested through Chi-square test (Sur et. al. 2013). To assess the degree of association between liquidity and profitability, three types of correlations, namely, Pearson's product 
moment correlation, Spearman's rank correlation and Kendall's rank correlation have been used whose significance has been tested through t-test.

\subsection{Analysis and Findings}

This section of the study has been discussed in three different parts, namely, analysis of liquidity; analysis of profitability; and relationship between liquidity and profitability.

\subsection{Analysis of liquidity}

Current ratio (CR) is one of the most used ratios indicating liquidity of a firm. It is the ratio of total current assets to total current liabilities and expresses the overall short term obligation paying capability of a firm. It measures whether the current assets, if realised right now, are enough to pay the current liabilities. Naturally, the higher the CR, the higher is the liquidity of a firm. From Table 1, it can be seen the trend of CR of HUL over the study period. The slope of the trend line is positive means the trend is an upward one. The slope, when tested through t-test, also shows that the trend is significant at $1 \%$ level of significance. It signifies that there is a very prominent and clear-cut upward trend in CR of HUL over the study period.

Table 1: Liquidity Ratios of HUL

\begin{tabular}{|l|c|c|c|c|c|c|c|}
\hline \multicolumn{1}{|c|}{ Year } & CR & QR & ITR & DTR & ACR & CDTR & CATA \\
\hline Dec' 05 & 0.64 & 0.33 & 8.47 & 21.86 & 0.13 & 2.24 & 0.42 \\
\hline Dec' 06 & 0.67 & 0.34 & 7.91 & 25.16 & 0.09 & 2.21 & 0.42 \\
\hline Dec' 07 & 0.63 & 0.25 & 7.11 & 30.94 & 0.06 & 2.22 & 0.48 \\
\hline March' 09 & 0.9 & 0.5 & 8.11 & 41.3 & 0.17 & 2.87 & 0.66 \\
\hline March' 10 & 0.8 & 0.47 & 8.15 & 28.97 & 0.27 & 1.81 & 0.56 \\
\hline March' 11 & 1.05 & 0.63 & 7.02 & 24.34 & 0.24 & 1.9 & 0.6 \\
\hline March' 12 & 1.21 & 0.82 & 8.79 & 27.27 & 0.27 & 2.15 & 0.71 \\
\hline March' 13 & 0.99 & 0.66 & 10.21 & 34.13 & 0.23 & 2.75 & 0.66 \\
\hline March' 14 & 1.03 & 0.71 & 10.2 & 33.96 & 0.23 & 2.7 & 0.68 \\
\hline March' 15 & 1.05 & 0.76 & 11.84 & 38.52 & 0.27 & 2.83 & 0.68 \\
\hline Mean & 0.90 & 0.55 & 8.78 & 30.65 & 0.20 & 2.37 & 0.59 \\
\hline Slope of the Linear Trend & 0.056 & 0.058 & 0.380 & 1.096 & 0.020 & 0.056 & 0.032 \\
\hline t stat & 4.25 & 5.61 & 3.25 & 1.74 & 3.59 & 1.38 & 4.91 \\
\hline P-value & 0.0028 & 0.0005 & 0.0118 & 0.1196 & 0.0071 & 0.2038 & 0.0012 \\
\hline Level of Significance & $1 \%$ & $1 \%$ & $5 \%$ & - & $1 \%$ & - & $1 \%$ \\
\hline
\end{tabular}

Source: Compiled and computed from published Annual Reports of HUL from 2005 to 2014-15

Note: Current ratio $(C R)$, Quick ratio $(Q R)$, Inventory turnover ratio (ITR), Debtors turnover ratio (DTR), Absolute cash ratio (ACR), Creditors turnover ratio (CDTR) and Current assets to total assets (CATA) 
QR indicates the liquid liability paying capability of a firm by using its liquid assets and is measured through the ratio of liquid assets to the liquid liabilities. The higher the QR, the higher will be the liquidity. In Table 1, we observe an upward trend in QR of HUL over the study period. Through the t-test, we have also seen that the slope of the upward trend is very prominent being significant at $1 \%$ level of significance.

ITR represents the number of times the inventory of a firm needs to be replaced for selling purpose in a year. The efficiency of inventory management of a firm can also be judged through this ITR. A high inventory ratio signifies that the firm can very quickly convert its inventory either directly into cash through cash sales or indirectly into cash via debtors through credit sales. Therefore, the higher the ITR, the higher is the liquidity of a firm. On the other hand, a low inventory ratio signifies storing of inventory in warehouse for a long time before making the sales. As a result, there will be an unnecessary delay in realising cash from inventory which in turn, reduces the capability to meet the short term obligations. From Table 1, it is observed that an upward trend is there in ITR of HUL over the study period and it is statistically significant at $5 \%$ level of significance.

DTR reflects the number of times the debtors are fully realised into cash in a year. It expresses the efficiency of a firm in credit collection. High DTR means it takes short time to collect dues from the debtors and in turn, it increases the short term obligation paying capability of the firm. Therefore, the higher the DTR, the higher will be the liquidity of a firm. From Table 1, we see an upward trend in DTR of HUL over the study period but the slope of the upward trend is not statistically significant which means the upward trend is not prominent.

ACR is the ratio of average cash and bank balance to current liabilities. It signifies the capability of a firm to meet its current liabilities by utilizing its ready cash and bank balance. Naturally, the higher the ACR, the higher will be the liquidity of a firm. In table 1, we observe an upward trend in ACR of HUL over the study period. The slope of the trend line is very prominent as it is significant at $1 \%$ level of significance.

CDTR represents the number of times the creditors of a firm are paid in full in a year. High CDTR means the creditors need to be paid within short time. So, there will be immediate outflow of cash which in turn, will reduce the liquidity of the firm. On the other hand, low CDTR represents that the creditors allow us credit of longer period which means there will not be immediate cash outflow on account of payment to creditors leading an increase in liquidity. In Table 1, we observe an upward trend in CDTR of HUL over the study period but the slope of the upward trend line is not prominent as it is not statistically significant. 
CATA represents the portion of current assets to total assets of the firm. Naturally, with the increase in CATA, the liquidity of the firm will also increase provided other conditions remain same. In Table 1, we see an upward trend in CATA of HUL over the study period. The upward trend is also very prominent as the slope of the trend line is statistically significant at $1 \%$ level of significance.

Therefore, from the calculations of Table 1, it is revealed that except CDTR all other indicators of liquidity give the evidence that the liquidity of HUL over the study period is increasing. Though CDTR shows that the liquidity of HUL is reducing over the study period, there is no need to emphasise on it as the result is not statistically significant. Among the other six indicators, only the result of DTR is not statistically significant but the results of remaining five indicators are statistically significant. So, keeping aside the insignificant results, we can opine that the liquidity of HUL over the study period is increasing.

Table 2: Computation of Ultimate Liquidity Rank

\begin{tabular}{|l|c|c|c|c|c|c|c|c|c|}
\hline Year & $\begin{array}{c}\text { Rank } \\
\text { on } \\
\text { CR }\end{array}$ & $\begin{array}{c}\text { Rank } \\
\text { on } \\
\text { QR }\end{array}$ & $\begin{array}{c}\text { Rank } \\
\text { on } \\
\text { ITR }\end{array}$ & $\begin{array}{c}\text { Rank } \\
\text { on } \\
\text { DTR }\end{array}$ & $\begin{array}{c}\text { Rank } \\
\text { on } \\
\text { ACR }\end{array}$ & $\begin{array}{c}\text { Rank } \\
\text { on } \\
\text { CDTR }\end{array}$ & $\begin{array}{c}\text { Rank } \\
\text { on } \\
\text { CATA }\end{array}$ & $\begin{array}{c}\text { Sum } \\
\text { of the } \\
\text { Ranks }\end{array}$ & $\begin{array}{c}\text { Ultimate } \\
\text { Liquidity } \\
\text { Rank }\end{array}$ \\
\hline Dec'05 & 9 & 9 & 5 & 10 & 8 & 6 & 9.5 & 56.5 & 9 \\
\hline Dec'06 & 8 & 8 & 8 & 8 & 9 & 4 & 9.5 & 54.5 & 8 \\
\hline Dec'07 & 10 & 10 & 9 & 5 & 10 & 5 & 8 & 57 & 10 \\
\hline March'09 & 6 & 6 & 7 & 1 & 7 & 10 & 4.5 & 41.5 & 7 \\
\hline March' 10 & 7 & 7 & 6 & 6 & 2 & 1 & 7 & 36 & 5 \\
\hline March' 11 & 2.5 & 5 & 10 & 9 & 4 & 2 & 6 & 38.5 & 6 \\
\hline March' 12 & 1 & 1 & 4 & 7 & 2 & 3 & 1 & 19 & 1 \\
\hline March' 13 & 5 & 4 & 2 & 3 & 5.5 & 8 & 4.5 & 32 & 4 \\
\hline March' 14 & 4 & 3 & 3 & 4 & 5.5 & 7 & 2.5 & 29 & 3 \\
\hline
\end{tabular}

Source: Compiled and computed from published Annual Reports of HUL from 2005 to 2014-15

We have used seven indicators to measure the liquidity of HUL. In all other indicators except CDTR, the higher the ratio, the higher is the liquidity of the firm. In case of CDTR, the lower the ratio, the higher is the liquidity. Keeping these in our mind, ranks have been assigned to the respective years in terms of each indicator, respectively. Then, the sum of the ranks obtained under different indicators by each period has been 
calculated. Obviously, the lower the sum, the higher will be the overall liquidity. Keeping it in our mind, we have assigned the ultimate liquidity rank to the accounting periods. As per our principle, the year ending on March' 12 has the highest liquidity and the year ending on December' 07 has the least liquidity.

To examine, whether these ultimate liquidity ranks truly represent the trend of liquidity of HUL over the study period, it is essential to know the degree of uniformity among these seven sets of ranks. To estimate the said degree of uniformity, Kendall's Coefficient of Concordance (W) has been computed. W comes to 0.4379 which is found to be statistically significant at $1 \%$ level of significance using Chi-square test at 9 degrees of freedom. Therefore, there is a significant degree of uniformity among the seven sets of ranks and that is why, ultimate liquidity ranks truly represent the trend of liquidity of HUL over the study period. The same can also be deduced from the value of ' $r$ ' (0.3442) which is the Spearman's average correlation coefficient computed on the ranks of all pairs of raters.

\subsection{Analysis of profitability}

We have used three ratios to measure the profitability of HUL, namely, Return on net worth (RONW), Return on capital employed (ROCE) and Return on Assets (ROA). These are the ratios of Profit after tax to net worth, Profit after tax to capital employed and Profit after tax to total assets, respectively. Average Profitability Ratio (APR) is just the simple average of these three ratios. Being the average, APR will be taken as the overall indicator of profitability of HUL in this study. It is obvious that the higher the RONW/ROCE/ROA/APR, the higher is the profitability of the company. In Table 3, we have fitted linear trend line to the time series of all these four ratios, respectively. In each of the four ratios, an upward trend is followed. Only the slope of the upward trend line of ROA is prominent and powerful as it is statistically significant at $10 \%$ level of significance. The slopes of the other three upward straight lines are not statistically significant. Therefore, it can be said that the overall profitability of HUL is increasing during the study period though the increasing trend is not significant enough from the statistical point of view.

We have three basic ratios for measuring profitability as we mentioned before. In each of these three indicators, the higher the ratio, the higher will be the profitability. Considering this principle, the accounting periods have been ranked respectively for each indicator. Just like the methodology applied previously in Table 2, we have assigned ultimate profitability rank to the study periods (Table 4). As per our calculations, the year ending on March' 13 secures the highest rank while the year ending on December' 05 secures the lowest rank in terms of profitability. 
Table 3: Profitability Ratios of HUL

\begin{tabular}{|l|c|c|c|c|}
\hline \multicolumn{1}{|c|}{ Year } & RONW & ROCE & ROA & APR \\
\hline Dec' 05 & 61.09 & 58.08 & 20.91 & 46.69 \\
\hline Dec' 06 & 68.14 & 64.32 & 24.45 & 52.30 \\
\hline Dec' 07 & 133.84 & 118.08 & 28.19 & 93.37 \\
\hline March' 09 & 121.13 & 111.16 & 29.53 & 87.27 \\
\hline March' 10 & 85.25 & 79.04 & 23.13 & 62.47 \\
\hline March' 11 & 86.72 & 65.09 & 22.69 & 58.17 \\
\hline March' 12 & 76.62 & 59.68 & 24.56 & 53.62 \\
\hline March' 13 & 142.01 & 98.44 & 32.97 & 91.14 \\
\hline March' 14 & 118.04 & 88 & 29.75 & 78.60 \\
\hline March' 15 & 115.87 & 88.95 & 31.65 & 78.82 \\
\hline Mean & 100.87 & 83.08 & 26.78 & 70.25 \\
\hline Slope of the Linear Trend & 4.552 & 1.073 & 0.862 & 2.162 \\
\hline t stat & 1.55 & 0.43 & 2.29 & 1.14 \\
\hline P-value & 0.1595 & 0.6774 & 0.0515 & 0.2876 \\
\hline Level of Significance & - & - & $10 \%$ & - \\
\hline
\end{tabular}

Source: Compiled and computed from published Annual Reports of HUL from 2005 to 2014-15

Table 4: Computation of Ultimate Profitability Rank

\begin{tabular}{|c|c|c|c|c|c|}
\hline Year & $\begin{array}{l}\text { Rank on } \\
\text { RONW }\end{array}$ & $\begin{array}{c}\text { Rank on } \\
\text { ROCE }\end{array}$ & $\begin{array}{c}\text { Rank on } \\
\text { ROA }\end{array}$ & $\begin{array}{c}\text { Sum of the } \\
\text { Ranks }\end{array}$ & $\begin{array}{l}\text { Ultimate } \\
\text { Profitability } \\
\text { Rank }\end{array}$ \\
\hline Dec' 05 & 10 & 10 & 10 & 30 & 10 \\
\hline Dec' 06 & 9 & 8 & 7 & 24 & 9 \\
\hline Dec' 07 & 2 & 1 & 5 & 8 & 2 \\
\hline March’ 09 & 3 & 2 & 4 & 9 & 3 \\
\hline March' 10 & 7 & 6 & 8 & 21 & 6 \\
\hline March’ 11 & 6 & 7 & 9 & 22 & 7 \\
\hline March' 12 & 8 & 9 & 6 & 23 & 8 \\
\hline March' 13 & 1 & 3 & 1 & 5 & 1 \\
\hline March' 14 & 4 & 5 & 3 & 12 & 5 \\
\hline March' 15 & 5 & 4 & 2 & 11 & 4 \\
\hline \multicolumn{6}{|c|}{$\begin{array}{l}\text { Kendall's Coefficient of Concordance }(W) \text { among three sets of Profitability Ranks is } 0.8653 \text { which is } \\
\text { found to be statistically significant at } 1 \% \text { level (Using Chi-square test) at } 9 \text { degrees of freedom. } \\
\text { Spearman's average correlation coefficient }(r) \text { is } 0.7979 .\end{array}$} \\
\hline
\end{tabular}

Source: Compiled and computed from published Annual Reports of HUL from 2005 to 2014-15 
Again, to estimate the degree of uniformity among these three sets of ranks, Kendall's Coefficient of Concordance (W) has been computed. The value of W comes to 0.8653 which is found to be statistically significant at $1 \%$ level of significance using Chi-square test at 9 degrees of freedom. Therefore, there is a significant degree of uniformity among the three sets of ranks. So, ultimate profitability ranks can be taken as the true representative of the trend of profitability of HUL over the study period. The same can also be inferred from the value of ' $r$ ' (0.7979) which is the Spearman's average correlation coefficient computed on the ranks of all pairs of raters.

\subsection{Relationship between liquidity and profitability}

In this section, we measure the degree of association between the liquidity and profitability of HUL over the study period. Ultimate liquidity rank (ULR) series (Table 2) represent the liquidity and ultimate profitability rank (UPR) series (Table 4) represent the profitability of HUL. Moreover, average profitability rank (APRK) has also been calculated on the basis of average profitability ratio (Table 3) which too represents the profitability of HUL. Therefore, correlation coefficients between ULR and UPR and between ULR and APRK have been computed respectively. Being the ranked data, Spearman's Rank Correlation and Kendall's Rank Correlation have been used here. Spearman's Rank Correlation is the simple product moment correlation between the two series of ranks. On the other hand, Kendall's Rank Correlation considers each possible pair of individuals and the order of this pair in the two rankings. After calculating the correlation coefficients, level of their significance has been tested through t-test. Both Spearman's Rank Correlation Coefficient and Kendall's Rank Correlation Coefficient in both the two cases are positive but none of the four rank correlation coefficients is statistically significant (Table 5). Therefore, in case of HUL, we don't observe the conventional reverse relationship between liquidity and profitability which is well known as liquidity-profitability tangle. Rather, we see a positive association between liquidity and profitability though the association is not significant from statistical point of view. Theoretically, there should be a negative relationship between liquidity and profitability. In the above results, we witnessed just reverse of it. Therefore, there is a need to look at the reasons for the observed result. To find out the reason behind this apparently contradictory result, we need to analyse the relationship between profitability and each indicator of liquidity separately.

In Table 5, we got a positive but insignificant correlation between profitability and liquidity. We have measured the liquidity of HUL by seven indicators. So now, we shall try to examine the degree and type of association between profitability and each of these seven individual indicators of liquidity respectively. Three types of correlations, 
namely, Pearson's product moment correlation, Spearman's rank correlation and Kendall's rank correlation have been used for this purpose. The computed correlation coefficients have been tested through t-test (Table 6).

Table 5: Correlation between Liquidity and Profitability

\begin{tabular}{|c|c|c|c|c|c|}
\hline Year & $\begin{array}{c}\text { Ultimate } \\
\text { Liquidity } \\
\text { Rank } \\
\text { (ULR) }\end{array}$ & $\begin{array}{c}\text { Ultimate } \\
\text { Profitability } \\
\text { Rank } \\
\text { (UPR) }\end{array}$ & $\begin{array}{c}\text { Average } \\
\text { Profitability } \\
\text { Rank } \\
\text { (APRK) }\end{array}$ & $\begin{array}{c}\text { Correlation } \\
\text { between ULR } \\
\text { and UPR }\end{array}$ & $\begin{array}{c}\text { Correlation } \\
\text { between ULR } \\
\text { and APRK }\end{array}$ \\
\hline Dec'05 & 9 & 10 & 10 & \multirow{10}{*}{$\begin{array}{l}\text { (i) Spearman's } \\
\text { Rank Correlation } \\
\text { is } 0.091 \text { which is } \\
\text { not found to be } \\
\text { significant. } \\
\text { (ii) Kendall's } \\
\text { Rank Correlation } \\
\text { is } 0.111 \text { which is } \\
\text { not found to be } \\
\text { significant. }\end{array}$} & \multirow{10}{*}{$\begin{array}{l}\text { (i) Spearman's } \\
\text { Rank Correlation } \\
\text { is } 0.018 \text { which is } \\
\text { not found to be } \\
\text { significant. } \\
\text { (ii) Kendall's } \\
\text { Rank Correlation } \\
\text { is } 0.067 \text { which is } \\
\text { not found to be } \\
\text { significant. }\end{array}$} \\
\hline Dec' 06 & 8 & 9 & 9 & & \\
\hline Dec' 07 & 10 & 2 & 1 & & \\
\hline March' 09 & 7 & 3 & 3 & & \\
\hline March' 10 & 5 & 6 & 6 & & \\
\hline March' 11 & 6 & 7 & 7 & & \\
\hline March' 12 & 1 & 8 & 8 & & \\
\hline March' 13 & 4 & 1 & 2 & & \\
\hline March' 14 & 3 & 5 & 5 & & \\
\hline March' 15 & 2 & 4 & 4 & & \\
\hline
\end{tabular}

Source: Compiled and computed from published Annual Reports of HUL from 2005 to 2014-15

Table 6: Correlation Matrix between Average Profitability Ratio and Individual Liquidity Ratios

\begin{tabular}{|c|c|c|c|c|c|c|c|}
\hline \multirow{2}{*}{$\begin{array}{c}\text { Types of } \\
\text { Correlation }\end{array}$} & \multicolumn{7}{|c|}{ Correlation between Average Profitability Ratio and Individual Liquidity Ratios } \\
\hline & $\mathbf{C R}$ & QR & ITR & DTR & ACR & CDTR & CATA \\
\hline Pearson & 0.065 & 0.057 & 0.277 & $0.809 * *$ & -0.068 & $0.640^{*}$ & 0.388 \\
\hline Spearman & -0.061 & 0.042 & 0.127 & $0.806 * *$ & -0.098 & 0.491 & 0.281 \\
\hline Kendall & -0.045 & 0.067 & 0.111 & $0.644 * *$ & -0.116 & 0.244 & 0.138 \\
\hline
\end{tabular}

Between CR and profitability, a positive association is found in Pearson's correlation but according to Spearman's and Kendall's correlation, negative association is there between these two. The similarity among all these three correlations is that none of these three results is statistically significant. Therefore, we can say that CR has failed to prove any significant contribution, positive or negative, on profitability of HUL over 
the study period. Between QR and profitability, positive association is found in all the three types of correlation but none of the results is statistically significant. The same, i.e. positive but insignificant association is also found between ITR and profitability and between CATA and profitability, respectively. Therefore, we shall not emphasise much on these sets of correlations.

In case of correlation between ACR and profitability, negative but insignificant association is found in the three varieties of correlations. Being insignificant, we shall not give much importance on the relationship between ACR and profitability. A significant positive association is found between DTR and profitability and therefore, it can be said that DTR influences profitability significantly. The association is positive which means with the increase in DTR, profitability also increases. Increase in DTR represents increase in liquidity. Therefore, in HUL, the effect of DTR increases liquidity and profitability both.

A significant positive association is found between CDTR and profitability in terms of Pearson's correlation. Though positive, the association as per Spearman's correlation and Kendall's correlation is not significant. Therefore, keeping aside the insignificant ones, we shall rather concentrate on the significant association. Pearson's correlation between these two variables is positive which means with the increase in CDTR, profitability increases. Increase in CDTR signifies decrease in liquidity. Therefore, in HUL, effect of CDTR decreases liquidity but increases profitability. Both DTR and CDTR increase profitability. So, there is no wonder that overall profitability has been increased. But we may consider whose influence on profitability is more significant. The association between DTR and profitability is significant at 5\% level of significance but the association between CDTR and profitability is significant at $1 \%$ level of significance. It proves that the influence of CDTR on profitability was more significant than that of DTR on profitability. On the other hand, DTR increases profitability but CDTR reduces liquidity. Now, the question is whose impact on liquidity is more significant. The p-value of the slope of DTR trend line was 0.1196 whereas that of the slope of CDTR trend line was 0.2038 (See Table 1). It signifies that the influence of DTR on liquidity was more significant than that of CDTR on liquidity. So, overall liquidity was increasing. For this reasons, both liquidity and profitability were increasing hand in hand.

\subsection{Conclusion}

The conventional notion is that when profitability increases, liquidity decreases. However, in case of HUL, we saw both can be increased at the same time. HUL has 
made this apparently impossible phenomenon into a possible one with their intelligent debtors' and creditors' management. During the study period, the average CDTR was 2.37 but the average DTR was 30.65 (See Table 1). It implies that HUL enjoys credit from their creditors on an average for 154 days but allows credit to their debtors on an average for 12 days. Average period of credit enjoyed was 12.83 times of average period of credit allowed. As a result of it, the company can use the credit allowed by its creditors in long term purposes. This principle accelerates the capability of earning profit. On the other hand, the company allows credit to its customers for a very short period of time which in turn, enhances the short term obligations paying capability. Thus, the company has managed to increase its liquidity and profitability hand in hand. To conclude, we can say that increase in profitability does not necessarily mean decrease in liquidity.

\section{References}

Ahmad, R. (2016). A study of relationship between liquidity and profitability of Standard Chartered Bank Pakistan: Analysis of financial statement approach. Global Journal of Management and Business Research, 16(1), 77-82.

Ajao, O. S. \& Small, O. S. (2012). Liquidity management and corporate profitability: Case study of selected manufacturing companies listed on the Nigerian stock exchange. Business Management Dynamics, 2(2), 10-25.

Alshatti, A. S. (2015). The effect of the liquidity management on profitability in the Jordanian Commercial Banks. International Journal of Business and Management, $10(1), 62-71$.

Arora, A.K. (2013). Negative working capital and its impact on profitability. The Management Accountant, March, 308-313.

Asaduzzaman, M. \& Chowdhury, T. (2014). Effect of working capital management on firm profitability: Empirical evidence from textiles industry of Bangladesh. Research Journal of Finance and Accounting, 5(8), 175-184.

Aziz, A. I., Sharif, A. A. \& Salih, D. G. (2017). Liquidity management and profitability in Islamic banks of Kurdistan region of Iraq: Cihan bank for Islamic investment and finance as a case study. International Journal of Research- Granthaalayah, 5(5), 73-87. 
Bandyopadhyay, P. (2012). Liquidity management in Indian corporate sector: A study of selected companies during the post-liberalization period. Doctoral Dissertation, Department of Commerce, University of Burdwan, West Bengal.

Bhunia, A., Khan, I. \& Mukhuti, S. (2011). A study of managing liquidity. Journal of Management Research, 3(2), 1-22.

Chukwunweike, E. V. (2014). The impact of liquidity on profitability of some selected companies: The financial statement analysis (FSA) approach. Research Journal of Finance and Accounting, 5(5), 81-90.

Das, S. (2012). Working capital management of HUL - A case study. International Journal of Research in Computer Application \& Management, 2(4), 102-107.

HUL Annual Reports. (various issues). Retrieved from www.hul.co.in.

Khidmat, W. B. \& Rehman, M. U. (2014). Impact of liquidity and solvency on profitability on chemical sector of Pakistan. Ekonomika Managament Inovace, 6(3), 313.

Shivakumar \& Thimmaiah, N. B. (2016). Working capital management - Its impact on liquidity and profitability: A study of Coal India Ltd. International Journal of ResearchGranthaalayah, 4(12), 178-187.

Sur, D., Maji, S.K., \& Banerjee, D. (2013). Liquidity management in PSUs in postreform era: A case study of BHEL. The Management Accountant, August, 941-946.

Tamragundi, A. N. \& Vaidya, P. N. (2016). Liquidity-profitability relationship: A study of ten leading FMCG companies in India. International Journal of Management, 7(7), 363-369. 